УДК 82.0

ББК 83
ГОТФРИД БЕНН И МАРТИН ХАЙДЕГГЕР

О СУЩНОСТИ ПОЭЗИИ. ИСТОРИЯ НЕСОСТОЯВШЕЙСЯ ВСТРЕЧИ

DOI: 10.22455/2500-4247-20I9-4-3-28-49

Исследование выполнено при финансовой поддержке РФФИ, грант № I8-31I-оог 68 «Поэтика философского мышления: культурная парадигма модерна и современные тенденции»

Аннотация: В центре внимания статьи - коллизия непростых взаимоотношений Готфрида Бенна и Мартина Хайдеггера. Великий поэт и выдающийся философ предстают здесь не только как очевидцы и выразители своей эпохи, но как теоретики и практики поэтического слова. Странность их связи становится понятной в контексте сопоставления их взглядов на природу поэзии. Предложенный Хайдеггером революционный подход, в котором искусство оказывается местом свершения истины, не находит у Бенна поддержки. Выдвигая в докладе «Проблемы лирики» свою версию предназначения поэзии, Бенн невольно выступает разоблачителем онтологических спекуляций Хайдеггера. Позиция Бенна, укорененная в его профессиональной работе с логосом, разительно отличается от хайдеггеровской. Свою демиургическую функцию, по мнению Бенна, слово не заимствует у бытия, сохраняя за собой абсолютный автономный статус. Эта автономия и возвышает поэзию до уровня священнодействия. Фрайбургский же мыслитель, хотя и нарекает язык «домом человеческого бытия», превращает пространство речи в «ничейный» топос, где слово призвано высветить вещь в ее истине и тем самым дать возможность проявиться неявленному - бытию.

ключевые слова: поэзия, философия, язык, бытие, Готфрид Бенн, «Проблемы лирики», Мартин Хайдеггер.

Информация об авторах: Оксана Анатольевна Коваль - кандидат философских наук, Русская христианская гуманитарная академия, наб. р. Фонтанки, д. I5A, I9IоII г. Санкт-Петербург, Россия. ORCID: оoоo-о0о3-47I8-6669

E-mail: ox.koval@gmail.com

Екатерина Борисовна Крюкова - кандидат философских наук, независимый исследователь, г. Санкт-Петербург, Россия.

E-mail: depiobo@gmail.com

Для цитирования: Коваль О.А., Крюкова Е.Б. Готфрид Бенн и Мартин Хайдеггер о сущности поэзии. История несостоявшейся встречи // Studia Litterarum. 2019. T. 4, № 3. C. 28-49. DOI: I0.22455/2500-4247-20I9-4-3-28-49 


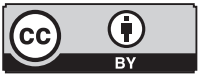

This is an open access article distributed under the Creative Commons Attribution 4.0 International (CC BY 4.0)

\section{GOTTFRIED BENN AND MARTIN HEIDEGGER ON THE ESSENCE OF POETRY. THE STORY OF A MIGHT-HAVE-BEEN MEETING}

\author{
(C) 20I9. O.A. Koval, E.B. Kriukova \\ Russian Christian Humanitarian Academy, \\ St. Petersburg, Russia \\ Received: April IO, 2019 \\ Date of publication: September 25, 2019
}

Acknowledgements: The paper is written with financial support from the Russian Foundation for Fundamental Research (RFFI), Project No. I8-3II-00268, "The Poetics of Philosophical Thinking: The Cultural Paradigm of Modernity and Contemporary Trends."

Abstract: The articles focuses on the complicated relations complicated relations between Gottfried Benn and Martin Heidegger. The great poet and the great philosopher were not only witnesses and spokesmen of their time, but above all theorists and practitioners of poetic word. The oddity of their connection becomes clear if we compare their views on the nature of poetry. A revolutionary approach proposed by Heidegger interpreting art as a place where truth is accomplished, does not find support in Benn. In his famous "Problems of Lyrical Poetry," Benn puts forward his own version of the purpose of poetry, and thus acts as an opponent of Heidegger's ontological speculations. Benn's position, rooted in his professional work with logos, is strikingly different from Heidegger's. According to Benn, the word does not borrow its demiurgic function from being, and thus retains its absolute autonomous status. This autonomy elevates poetry to the level of sacred rites. As for Heidegger, although he calls language "the home of human existence," he turns the space of speech into a "no man's" topos, where the word is intended to highlight the truth of the thing and thereby gives an opportunity to manifest the undermanifested, e.g. being.

Keywords: poetry, philosophy, language, being, Gottfried Benn, "Problems of Lyrical Poetry," Martin Heidegger.

Information about authors: Oxana A. Koval, $\mathrm{PhD}$ in Philosophy, Associate Professor, Russian Christian Academy for the Humanities, Fontanka River Embankment St. I5A, I9IOII St. Petersburg, Russia. ORCID: 0000-0003-47I8-6669

E-mail: ox.koval@gmail.com

Ekaterina B. Kriukova, PhD in Philosophy, Independent Researcher, St. Petersburg, Russia.

E-mail: depiobo@gmail.com

For citation: Koval O.A., Kriukova E.B. Gottfried Benn and Martin Heidegger on the Essence of Poetry. The Story of a Might-Have-Been Meeting. Studia Litterarum, 2019, vol. 4, no 3, pp. 28-49. (In Russ.) DOI: 10.22455/2500-4247-2019-4-3-28-49 
О небе, любви и могиле известно каждому,

И этим мы заниматься не будем,

Все сказано и проработано «культурным слоем».

Новизну сохраняет лишь вопрос словосочетания,

И это вопрос насущный:

А чего ради мы вообще стремимся что-то выразить?

Готфрид Бенн. «Словосочетание»

В середине І930-х гг., получив всеобщее признание как автор «Бытия и времени», Хайдеггер неожиданно меняет фокус своего онтологического вопрошания и обращается к искусству. Постепенно все отчетливее проступает и новая тема поздней философии Хайдеггера - язык, который символически приравнивается к голосу самого бытия. В отличие от Витгенштейна, который примерно в те же годы концентрируется на языке в его непритязательной роли обыденной речевой практики, фрайбургский мыслитель возводит логос в ранг едва ли не сакрального медиума, доступ к которому открывается лишь избранным: философам либо поэтам. Из маргинального для традиционной метафизики предмета, относимого к сфере эстетики, поэзия под пером Хайдеггера вдруг превращается в «событие явленности истины». И хотя чаще всего он демонстрирует свою теорию на классических образцах, апеллируя к античной трагедии или раскрывая потаенный смысл гимнов Гёльдерлина, его внимание привлекает и современная лирика. Речь идет не только о Рильке и Тракле, творчеству которых Хайдеггер посвятил отдельные сочинения, но и о таких крупных фигурах послевоенной поэтической сцены, как Пауль Целан, Ингеборг Бахман и Готфрид Бенн. 
Среди поэтов учение, проповедующее спасительную силу лирического начала, казалось бы, не могло не найти ответного отклика. И случай Целана во многом это подтверждает. Очарованный глубиной хайдеггеровских прозрений, Целан считал, что обрел в лице философа единомышленника и соратника в деле спасения языка. Только личное знакомство, внесшее некоторый диссонанс в их непростые взаимоотношения, ослабило магическое воздействие возвышенных спекуляций Хайдеггера. Что касается Ингеборг Бахман, то она еще со студенческих лет открыла для себя сочинения мыслителя. В своей диссертации, венчавшей курс философского обучения в австрийских университетах, Бахман осуществила критическое разбирательство хайдеггеровских воззрений, развивая подход своего учителя Виктора Крафта, последнего представителя Венского кружка. Несмотря на то что в диссертации она занимала довольно воинственную позицию в отношении самобытной манеры Хайдеггера, идеи «Бытия и времени» оставили неизгладимый след в мировидении Бахман: если в ее ранней поэзии, затрагивающей предельные вопросы временности человеческого существования, ощущается солидарность с мыслью, сосредоточенной на индивидуальном Dasein (даже в названии первого стихотворного сборника Бахман, «Отсроченное время» (1956), специалисты усматривают отголосок хайдеггеровских интуиций), то в поздний период, отмеченный решительным отказом от рифмованного слова и переходом к прозе, наблюдается явная конфронтация с философом (в романном цикле «Виды смерти» Бахман словно бы оспаривает ключевые концепты фундаментальной онтологии: страх, бытие-к-смерти, просвет и др.). При этом она сознательно избегала сближения со знаменитым мыслителем, так и не простив ему былые симпатии к национал-социализму. Желание Хайдеггера увидеть в своем юбилейном сборнике ее стихи Бахман категорически отвергла. На этом их личные контакты закончились, не успев начаться.

Ситуация с Готфридом Бенном и вовсе не однозначна: с одной стороны, пересечение поэта с философом было практически предопределено - общим умонастроением, образом жизни, самим временем; с другой оставаясь верны себе, они сосуществовали не столько в поле притяжения, сколько взаимоотталкивания. Если Хайдеггер выстраивал теорию, в которой утверждался универсальный смысл языка, то Бенн в своей поэтической практике стремился ухватить конкретность формы. Если Хайдеггер возно- 
сил стихи на высоты сверхчеловеческого откровения, то Бенн спускался с ними в инфернальные глубины подсознания. Если Хайдеггер обживал язык с целью обрести то, что стоит за словами, - истину бытия, то Бенн творил это бытие непосредственно из самих слов. Несостоявшаяся встреча, которая даже в регистре своего отсутствия оказывается событием значимым, свидетельствует об исключительности как ее (не)участников, так и того напряжения, которое возникает между полюсами философии и поэзии, когда речь заходит о назначении и природе последней.

На первый взгляд, все способствовало тому, чтобы между Бенном и Хайдеггером, двумя выдающимися представителями своего поколения, установились крепкие связи. Оба происходили из клирикальных семей, в которых царил дух сурового аскетизма. Правда, Бенн по вероисповеданию протестант, а Хайдеггер - католик, позднее, при заключении брака, принявший лютеранство. Оба родились в маленьких городках, провинциальный дух которых не пытались изжить в себе, а, напротив, превратили в предмет особой гордости. Правда, Бенн всегда подчеркивал, что он северянин, тогда как Хайдеггер считал, что подлинный немец - это шваб. Оба в юности оставили религию своих отцов, хотя навсегда сохранили чувство благоговения перед святостью. Оба даже начинали университетское обучение с теологии. Хайдеггер вскоре сменил специализацию, выбрав философию, Бенн же предпочел медицину. Оба с воодушевлением приветствовали приход национал-социалистов к власти, увидев в этом возможность «нового начала» для народа Германии: Бенн печально прославился своим открытым письмом Клаусу Манну под названием «Ответ литературным эмигрантам» (I933) и докладом на радио «Новое государство и интеллектуалы» (I933), Хайдеггер же при вступлении в должность ректора произнес патетическую речь «Самоутверждение немецкого университета» (I933). Правда, симпатии Бенна довольно быстро уступили место глубокому сожалению (см.: [І9]), тогда как разочарование Хайдеггера, несмотря на уход с поста ректора, - вопрос открытый (см.: [го]). И тот, и другой, добившись на заре национал-социалистического господства высокого положения в своей профессиональной среде, лелеяли планы по ее коренному переустройству: Бенн мечтал реформировать Прусскую академию искусств, Хайдеггер ратовал за упразднение традиционной формы университета и его полное обновление - но планы эти провалились. После войны обоим ввиду поддержки фашистского режи- 
ма было запрещено публиковаться. В случае Бенна этот запрет стал лишь продолжением наложенных на него еще нацистами ограничений. В творчестве обоих прослеживается резкий контраст между ранними и поздними философскими или поэтическими опытами, что заставляет исследователей говорить о намеренном «повороте». Однако он не был связан с политическими переменами: и тот, и другой продолжали придерживаться консервативных взглядов, разве что избегали излишней публичности, ведя довольно замкнутое существование, что не помешало им еще при жизни стать культовыми фигурами не только у себя на родине, но и далеко за ее пределами. Да и в мировоззренческом плане Бенн и Хайдеггер схожи: оба влюблены в античную Грецию, оба - враги Просвещения с его дифирамбами человеческому разуму, оба - противники идеи гуманизма и набирающей силу технической цивилизации.

Идея свести поэта с мыслителем не раз посещала их современников, а в кругу общих знакомых стала едва ли не навязчивой. В числе наиболее предприимчивых организаторов предполагаемой встречи стоит назвать литературного критика и театрального деятеля Эгона Вьетту, страстного почитателя как хайдеггеровской философии, так и стихов Бенна, и профессора Штроомана, главного врача престижного санатория, где Хайдеггер впервые после войны начал выступать с докладами и обрел благодарную аудиториюг. Для Вьетты, который вел переписку с поэтом еще с г930-х гг., не было сомнений, что Бенн и Хайдеггер говорят об одном, образуя «единый фронт» немецкой культуры, а потому их знакомство - судьбоносная веха в истории Германии. В своих статьях, посвященных лирике Бенна, Вьетта трактует его поэзию, всецело следуя не только духу, но и букве хайдеггеровских текстов, так что создается впечатление, будто эпохальная встреча для автора уже состоялась. Штрооман, устроив в Бюлерхёэ очередные чтения Хайдеггера, слал Бенну одно за другим письма с просьбой приехать. «Не обижайтесь на многочисленные приглашения Штроомана... Это не навязчивость, а сокровенная мечта романтика о звездном часе человечества (ко-

I To, что происходило в стенах лечебницы, имеет своим прообразом романтическую атмосферу санатория «Берггоф» из «Волшебной горы» Томаса Манна. Не исключено, что и Хайдеггер мыслил свою миссию как врачевательную, просвещая жаждущих прежде всего духовного исцеления пациентов. Ареол, которым Томас Манн сумел окружить болезнь, сделав ее состоянием особой чувствительности к предельным вопросам, объединял как организатора чтений, так и самого лектора, не говоря уже о высокородной публике. 
торого не существует): встреча Хайдеггер-Бенн» [I5, S. I49], - уговаривает поэта его давний корреспондент Фридрих Вильгельм Эльце, которому Бенн привык поверять все свои заботы и тревоги.

С конца I940-х гг. «сердечные приветы» и «наилучшие пожелания» циркулировали между Берлином, откуда Бенн практически не отлучался, и Фрайбургом, где обретался Хайдеггер, регулярно - однако всегда только через третьих лиц. После того как в 1948 г. в Швейцарии увидел свет первый послевоенный сборник Бенна «Статические стихи», репрезентирующий совсем другого поэта, далекого от закрепившегося за ним со времен «Морга» (1912) образа декадентствующего нигилиста², Хайдеггер внимательно следит за каждой появляющейся публикацией немецкого лирика. Он просит своего знакомого книготорговца Фрица Вернера сообщать ему обо всем, что выходит из-под пера Бенна. В разговорах с разными людьми, в частности, с Вьеттой или с Хансом Пешке, издателем литературного журнала «Меркур», Хайдеггер высказывается о творчестве Бенна в превосходных выражениях. Многие из этих похвал доходят и до самого поэта, что ему чрезвычайно приятно слышать. «Получил письмо от Вьетты с сообщением из уст Хайдеггера о томе стихов, который Вы были столь любезны ему дать (имеется в виду сборник Бенна «Пьяный поток» (І949), который Эльце некоторое время назад послал мыслителю. - O.К., Е.К.), - пишет он своему другу. - На удивление прекрасные и тронувшие меня слова» (письмо к Эльце от 6.0I.1950) [15, S. 234].

Бенн, по большей части безразличный к тому, что происходит в интеллектуальном мире, со своей стороны, тоже интересуется Хайдеггером. Он ставит его в один ряд с такими корифеями, как Ницше и Шпенглер, чей авторитет для поэта на протяжении всей жизни сохранял абсолютную бесспорность. Комментируя незадолго перед тем опубликованные в Берне под одной обложкой тексты Хайдеггера «Учение Платона об истине» и «Письмо о гуманизме» (I947), Бенн комплиментарно отзывается о философе: «...я читал его новую книжицу - без сомнения, он (Хайдеггер. - O.К., Е.К.) возвышается надо всем - над всеми, кто профессионально думает, учит, преподает, ни Ясперс, ни Шпрангер даже близко не стояли» (письмо к Эль-

2 Хотя Бенн уже с начала І920-х гг. изменил своей прежней манере эпатажной чувственности и стал тяготеть к ясности и чистоте классического стихосложения, в нем еще долго не желали видеть никого, кроме яркого представителя экспрессионизма. 
це от 6.06.I949) [I5, S. IOI-IO2]. В то же время восторги Бенна не мешают ему сохранять критическую дистанцию по отношению к идеям мыслителя, которые сознательно подаются их автором как новаторские, революционные, решительно порывающие с традицией:

Должен Вам признаться, иногда я думаю, что у Х. речь идет о давно уже известных вещах, старейших накоплениях философии, которые он всего лишь по-новому «толкует», причем не без зазнайства. И вот вокруг этого он и пляшет! Ничего хорошего! (письмо к Эльце от 28.Iо.I949) [15, S. I88].

Однако, когда до Бенна доходят слухи, что он якобы не до конца понял глубину хайдеггеровских прозрений и в лучшем случае стоит на пороге обретения онтологической истины, лирик возмущен подобными предположениями на его счет (см.: [15, S. II6, 428]).

Безусловно, Бенн не входил в число адептов хайдеггеровского творчества, которые на лету ловили каждое слово философа и принимались рассуждать исключительно в изобретенных им категориях, каковые Адорно остроумно назвал «жаргоном подлинности». Но причислять его к дилетантам аналитической рефлексии со стороны приверженцев хайдеггерианства было крайне опрометчиво. Даже если не брать в расчет обширный круг чтения классиков западной мысли, уже одни только связи Бенна с видными современными теоретиками могут служить подтверждением его серьезного интеллектуального бэкграунда. Общение со знаменитым филологом Эрнстом Робертом Курциусом, встреча с которым в 1949 г. положила начало их интенсивной переписке, оказалось весьма продуктивным для Бенна: фундаментальный труд Курциуса «Европейская литература и латинское Средневековье (I948) вдохновил лирика артикулировать собственное профессиональное кредо3. Тот же Адорно, который принадлежал к идейно враждебному лагерю и акцентировал весьма неудобный для Бенна травматический опыт Германии, случайно познакомившись с поэтом в I954 г. на

3 Бенну импонировали убеждения Курциуса касательно важности формального принципа при построении художественного текста. Помимо стихотворных посвящений, он упоминает ученого и в своем автобиографическом опусе «Двойная жизнь» (I950): «За последние десятилетия мне попалась только одна работа, в которой литературные произведения большого временного периода исследуются с точки зрения эстетической формы, это книга Э.Р. Курциуса» [2, с. 220]. 
научном симпозиуме в Бад-Вильдунгене, нашел его крайне интересным собеседником. Бенн тоже почувствовал расположение к Адорно, что впоследствии склонило его согласиться участвовать в радиопередаче, где предполагалось свести двух мэтров в дискуссии на тему «Чистое и ангажированное искусство», которая в итоге так и не состоялась - по обоюдному желанию отложить, но не отменить, эту встречу (см.: [18]).

С мыслителями консервативного круга, как ни странно, отношения у Бенна складывались гораздо менее гладко. С одной стороны, он искал в сочинениях таких философов, как Юлиус Эвола, Карл Шмитт, Эрнст Юнгер, Арнольд Гелен, метафизическую опору собственным представлениям, с другой - ни одна из известных ему концептуальных систем не могла удовлетворить его духовные запросы. Так, поначалу Бенн был очень воодушевлен эзотерическими опусами Эволы и даже написал рецензию к немецкому изданию его работы «Восстание против современного мира» (1934). Однако, несмотря на свою завороженность культурфилософскими проектами Эволы, ударяющегося в мифопоэтические фантазии о развитии и гибели цивилизаций, об аристократической власти духа, о древности и чистоте арийской расы, Бенн интуитивно ощущает опасность идей, изложенных в декларативном труде итальянца «Языческий империализм» (I928), и постепенно отдаляется не только от автора, прекращая с ним всяческую переписку, но и от политического режима, реализующего подобные фантазии в Германии ${ }^{4}$.

Если от общения с Эволой сохранилось лишь одно-единственное письмо I955 г., в котором тот предлагает возобновить довоенные связи (скорее всего, оно так и осталось без ответа), эпистолярные контакты Бенна с Юнгером доступны в гораздо большем объеме. Другое дело, что их обмен посланиями носит по большей части церемониальный характер и не проливает свет на природу этих взаимоотношенийг. Известно, что еще молодым человеком Юнгер - под впечатлением от прозы Бенна о мрачных буднях врача Рённа (новеллы, составившие цикл «Мозги», І9І6) - написал ему восторженное письмо, надеясь на ответную реакцию, которой не по-

\footnotetext{
4 О том, как менялось восприятие Бенном теорий Эволы, см. обстоятельный отчет Юргена Шрёдера, опирающийся на анализ текстов: [21, S. I64-I70].

5 См. остроумное послесловие издателя переписки Хольгера Хофа в книге:

[12, S. 139-150].
} 
следовало. Вторую попытку завязать знакомство он предпринял тридцать лет спустя, уже в статусе маститого автора, послав Бенну свой роман «Гелиополь» (I949) с длинным посвящением и выражением признательности. Личная встреча (первая и последняя) состоялась в I952 г., однако со стороны поэта это было не более чем проявлением вежливости. И хотя Бенн прямо не выказывал своих сомнений насчет образа жизни и воинственной позиции Юнгера, его настороженность, и даже неприятие, проскальзывает не только в доверительных беседах с Эльце. Стихотворение «Идеальное существование?», поводом для которого послужила почтовая карточка от Юнгера («На антибской открытке, / Полученной мною сегодня, / Средиземноморский замок, / Воистину фантастическое зрелище: / Юг, море, снег, горный склон...» [4, с. 367]), показывает, в сколь разных мирах обретались мыслитель - вечный искатель приключений, и поэт, с каждым годом все больше погружавшийся в свою «внутреннюю эмиграцию». В известном пятистишии «Эрнсту Юнгеру» также звучит желание отмежеваться, хотя оно и затмевается совершенством поэтической формы:

Нас называют воедино.

В душе чужие мы с тобой,

Но делим поровну - годины,

Раденья, раны и руины

Того, что мнит себя судьбой [9, с. 48I].

Бенн испытывал раздражение из-за того, что его имя из года в год упоминалось журналистами через запятую с именем Юнгера: его не только не прельщала жизненная философия человека, с которым его так откровенно отождествляли, но и сердило содержание сочинений, а равно и манера, в которой оно подавалось. Чтение юнгеровских «Излучений» вызвало у поэта настоящий приступ гнева:

...катастрофично! Рыхло, чванливо, претенциозно и без всякого стиля. По языку - сомнительно, по характеру - ничтожно. Иногда приближается к какому-то знанию, иногда - к некоторой глубине, но никаких прорывов, стройности, огня (письмо к Эльце от 7.оI.I948) [І4, S. 288]. 
На этом фоне сдержанность, с которой Бенн оценивает Хайдеггера, кажется едва ли не похвалой: «...я не имею ничего против сопоставления с Хайдеггером, для меня это честь - в отличие от аналогий с Ю.» (письмо к Эльце от I9.IO.I949) [I5, S. I84]. Однако бахвальство и самовлюбленность, которые столь резко осуждает Бенн в Юнгере, в какой-то мере присущи и фрайбургскому философу, ничуть не сомневавшемуся в собственном превосходстве над современниками и адресовавшему свои бытийно-исторические прозрения потомкам. Если не предметно, то по крайней мере «на слух» Бенн с его обостренным поэтическим чутьем уловил претенциозные интонации в хайдеггеровских речах. «Разъяснения к поэзии Гёльдерлина» (1936), которые спровоцировали в Германии всплеск небывалого интереса к почти забытому романтику, не привели поэта в восторг, а, скорее, породили в нем скепсис - может быть, именно потому, что вопросы, затрагиваемые Хайдеггером в данном случае, непосредственно вторгались в зону профессиональной компетенции Бенна. В стихотворении «Досадно» (I953), построенном в виде монотонного перечисления удручающих событий повседневности, незначительность которых становится очевидной в преддверии надвигающейся смерти, лирический герой сетует и на то, что не владеет навыком риторических уловок. Констатируя эту свою несостоятельность: плохо, мол, «когда новую мысль / не запакуешь в гельдерлиновский стих, / по примеру профессоров» [3, c. 203], - Бенн явно намекает на Хайдеггера. Стало быть, глубокомысленные заявления философа о поэзии воспринимаются им всего лишь как упражнения в стиле, причем не самые честные.

Когда в мае г952 г. поэт прочитал в журнале «Меркур» недавно транслировавшийся по радио доклад Хайдеггера «Что зовется мышлением?», где обыгрывается гельдерлиновская строка «Мы знак, без значенья», он отозвался о нем так: «...много шума из ничего, в котором интерес представляет лишь подчеркивание и отсылание к этому самому ничто» (письмо к Эльце от 7.07.I952) [16, S. I36]. Набирающая силу популярность хайдеггеровской философии расценивается Бенном как модное поветрие. Абстрактные категории с предельно доверительными наименованиями: заброшенность, экзистенциальный ужас, скука, забота, тревога, вина, конечность оказались тогда крайне созвучными умонастроениям послевоенной Германии. Правда, по мнению Бенна, понятийный словарь фундаментальной онтологии нарочито усугублял повсеместное ощущение 
безвыходности, делая его приемлемым и даже эстетически комфортным. В опубликованном только post mortem стихотворении «Малое культурное обозрение» Бенн иронически описывает состояние своей эпохи, в котором разговоры о бесприютности человека на земле перемежаются стремлением взять от жизни всё что можно:

А если уж говорить о страхе перед жизнью:

Угорь на завтрак,

Вечером океан, безграничность,

Ночью ощущение покинутости зато как славно засыпается!

Обороняться Европе более не угодно:

Ей хочется страха, ей хочется покинутости $[5, \text { c. 483 }]^{6}$.

Выпады против Хайдеггера встречаются не только в стихах и письмах Бенна. В эссе «Старость как проблема художника» (г953), где поэт, оглядываясь на прожитый век, поднимает проблемы человеческой бренности и собственного предназначения, он, хотя и мимоходом, но совершенно недвусмысленно высказывается о теории искусства Хайдеггера, которая впервые была изложена в трактате «Исток художественного творения» (I936). В своей работе Хайдеггер с радикальной прямолинейностью пытался опровергнуть общепринятые толкования произведения искусства, настаивая на том, что оно - место явленности истины, а не красоты. Последняя не отрицается, но получает подчинительное значение, препоручая свою феноменальность в распоряжение незримого бытия: «Красота есть способ, каким бытийствует истина - несокрытость» [Іі, с. 87]. Полотно Ван Гога «Башмаки», приводимое Хайдеггером в пример, мыслится как особый топос, в котором не просто изображаются конкретные предметы, а обнаруживает себя исходная сущность всех вещей, их бытийное начало:

Что же совершается здесь? Что творится в творении? Картина Ван Гога есть раскрытие, растворение того, что поистине есть это изделие, крестьянские башмаки. Сущее вступает в несокрытость своего бытия... В творе-

6 Бенн в этом отрывке намеренно использует хайдеггеровский неологизм «заброшенность» (Geworfenheit). 
нии, если в нем совершается раскрытие, растворение сущего для бытия его тем-то и таким-то сущим, творится совершение истины [II, с. 69].

Исходя из предложенной интерпретации имплицитной задачей художника становится порождение истины, при этом автор парадоксальным образом лишается своих демиургических функций, превращаясь в своеобразный инструмент мистического действа, разыгрываемого самим бытием.

Совсем не требуется, чтобы созданное свидетельствовало о великом достижении большого мастера и чтобы в результате этого сам мастер поднялся в глазах общества. Совсем не нужно, чтобы стало известно: N. N. fecit*, но в творении должно удерживаться в просторах разверстого самое простое: factum est**, именно то, что здесь свершилась несокрытость и что совершившееся еще только совершается... [Іг, с. 96].

Не обольщаясь оригинальностью подобного подхода, не подпадая под обаяние переизобретенного Хайдеггером языка, не поддаваясь суггестивной силе его провокаций, Бенн адресует автору вопрос по существу:

...когда большой философ пишет, что искусство есть «вхождение истины в творение» - что это опять-таки за истина? Истина из эскизов и набросков, из ручного производства, или истина скорее лишь упоминается, чтобы представить заглавные буквы философии, поскольку в искусстве речь об истине не идет, речь идет о выражении [8, с. 443].

Когда дело касается творчества, Бенн опирается на собственный опыт и потому судит не отвлеченно, а вполне определенно. Для него создание стихов - это прежде всего работа с формой, изматывающий, кропотливый поиск единственно необходимого слова. Он знает, что только путем бесконечного перебирания вариантов может появиться абсолютное стихотворение, чье совершенство не имеет ничего общего со «спором мира и земли» (как аттестует истину Хайдеггер). Важна лишь артикуляция, мелодика речи, конструкция фразы. Тонкость и точность выражения - идеал,

* Такой-то сделал (лат.)

** Сделано (лат.). 
к которому поэт способен приблизиться всего несколько раз за свою многолетнюю практику7. Учитывая столь строгие критерии, предъявляемые в первую очередь к себе, не покажется странным, что умозрительные рассуждения о бытии, «просвечивающем» в произведении искусства, привели Бенна в ярость:

Онтология - где это самое бытие, кроме как на моих картинах, и что там все время с вещами? Вещи возникают потому, что их признают, то есть формулируют, пишут на холсте, а если их не признают, они исчезают в небытии, лишенные сущностного начала. Эти мыслители с их основанием бытия, невидимым никому, лишенным формы и очертаний, сплошь трактаты, сплошь трактатчики <...>. Никто ничего не завершает, не доводит до конца, я должен сам изготавливать свои вещи [8, с. 439].

Полная идентификация себя с художником, о котором говорится в тексте Хайдеггера, позволяет Бенну возражать философу не извне в качестве случайного читателя, а словно бы изнутри - из глубины затрагиваемой проблемы. Причем именно эмоциональность - лучшее свидетельство тому, что Бенн отлично понял мысль Хайдеггера. Понял и не согласился с ней.

Вероятно, причины размежевания кроются в том, что за несколько лет до статьи о старости Бенн имел случай представить авторскую концепцию поэтического искусства ${ }^{8}$. Оттого его сокрушительную критику можно считать тоже в некотором роде философским ответом Хайдеггеру. В своем самом знаменитом докладе «Проблемы лирики» (г95I) Бенн выдвинул теорию, которая, несмотря на близость хайдеггеровскому терминологическому аппарату, тем не менее содержит ряд принципиальных отличий. В частности, ключевое для философа понятие «бытие» поэт использует скорее

7 «...ни один, даже величайший, лирик нашего времени не оставит после себя больше шести-восьми совершенных стихотворений; остальные могут представлять интерес с точки зрения биографии автора или его внутреннего развития, но самодостаточных, излучающих непреходящий свет и очарование - таких мало: и ради этих шести стихотворений - от тридцати до пятидесяти лет аскезы, страданий, борьбы» [7, с. 394].

8 По мнению Бенна, одной из существенных черт новейшей поэзии является саморефлексия художника: «Современный лирик (помимо произведений) создает собственную философию композиции и творческую систему» [7, с. 387]. 
прикладным образом, чтобы объяснить свою основополагающую мысль о приоритете формы в произведении искусства.

...форма - это и есть стихотворение. Мы можем сказать о стихотворении, что его содержанием служат печаль, страх, убеждения, которые есть у каждого, но все это - общечеловеческое достояние, общечеловеческий капитал, более или менее сублимированный в словах; лирика возникает только тогда, когда всему этому придана форма, которая делает содержание самодостаточным, поднимает его, придает ему с помощью слов очарование. Изолированная форма, форма как таковая - вообще не существует. Форма - это бытие, это экзистенциальная задача художника, его цель [7, с. 395].

Создание формы, которая в онтологическом плане бесконечно превышает какое бы то ни было содержание, поскольку выводит его из режима еще-не-сущего и впервые утверждает в существовании, приравнивается Бенном к индивидуальному жизненному проекту, по своей метафизической мощи не уступающему «подлинной фактичности Dasein». Труд художника, который «должен сам изготавливать свои вещи», получает в версии Бенна значение поистине философского вопрошания, когда вопрошающий ставит себя под вопрос, с тем чтобы в конечном итоге в очертаниях поэтической формы обрести собственные границы.

Я бы сказал, что за каждым стихотворением в очень сильной степени ощущается присутствие автора, его сущность, его бытие, его внутренние обстоятельства, таким образом в стихотворение входят и «темы» и «содержание»... А в целом я считаю, что у лирики нет никакого другого «предмета», кроме самого лирика [7, с. 396-397].

Если акцентирование языковой формы роднит идеи Бенна с более поздними структуралистскими теориями, то в отношении фигуры автора речь здесь идет скорее не о смерти субъекта, а о его рождении. Проблематичность лирического Я связана для Бенна (как и для Ролана Барта) с недоосуществленностью, которую и призвано восполнить появление стихотворения. 
Лирическое «я» - это разорванное «я», в пробоинах и разрывах, «я»-решетка, гонимое, обреченное на печаль. Но оно постоянно ждет своего часа, когда в мгновение ока оно встрепенется, ждет своего «южного ветра», волнения, порыва, чтобы нарушить привычные связи, вырваться с обыденной действительности на свободу, которая и создаст стихотворение - из слов [7, с. 398].

Сами стихи, согласно Бенну, который с примерной честностью пытается воспроизвести в своем докладе полный цикл творческого процесса, возникают как результат сверхчеловеческого напряжения между двумя полюсами, одним из которых выступает индивидуальное сознание, а другим - язык. Почти предугадывая бартовские интуиции, Бенн характеризует вербальный универсум как «язык с тысячелетней историей, со словами, на которых поэты прошлого оставили свой след, свою чеканку, который окрасили своими эмоциями, своими смыслами» [7, с. 402]. Противопоставление себя этому языку, в равной мере родному и чужому, мобилизует лирическое Я на сражение со столь явно превосходящими силами противника, с корпусом всей возможной речи. И хотя участь лирика, по-видимому, предрешена, его усилия, заведомо обреченные на поражение, иногда венчает «чудо, маленькая строфа из четырех строчек» [7, с. 402], или, если воспользоваться другой метафорой Бенна, в его руках вдруг оказывается

нить Ариадны, которая выведет его из этого биполярного напряжения, выведет с абсолютной безошибочностью, потому что - и это главная загадка стихотворение готово, прежде чем его начали писать, просто автор пока не знает точного текста. Законченное же стихотворение может звучать только так, как звучит, и никак иначе [7, с. 394].

Присутствие готового произведения в нерасчлененной массе языка тоже напоминает новаторские идеи структуралистской школы. Однако Бенна интересует, как аккумулируемая языком сила оживает в определенной конструкции предложения, а не то, что она может быть использована в идеологических целях. Отсюда его одержимость проблемой выражения, строением фразы, экспрессией формы: «Стиль выше истины, он несет в себе доказательство существования» [2, с. 229]. Верный своему духовному учи- 
телю Ницше, поэт готов оправдать бытие только как эстетический феномен. Способ говорения у него незаметно перетекает в способ экзистирования: нет жизни вне искусства, а соответственно, бытия - вне его конкретного выражения, идет ли речь о картине Ван Гога или о стихотворении Штефана Георге. В чем Бенн с Хайдеггером солидарен, так это в убежденности, что только поэзии по силам спасти мир от бесконечного падения в пропасть. Другое дело, что Хайдеггер проповедует возвращение к утраченному в древности истоку, к архаическому сплаву поэзии и философии, тогда как Бенн не склонен умалять настоящее. Новаторство и экспериментирование в области языка приветствуется им в качестве еще одной реализованной возможности речи, а стало быть, еще одного способа экзистенциального сопротивления ничто:

Артистизм - это попытка искусства в условиях общего кризиса содержания ощутить себя самое как содержание и из этого ощущения создать новый стиль, это попытка выдвинуть в противовес всеобщему нигилизму новую трансцендентальную ценность: творческую страсть [7, с. 390].

Тот пафос, которым Бенна вооружил Ницше, а именно предпочтение выражения содержанию, «пренебрежение субстанцией в пользу экспрессии» [6, с. 382], показался Хайдеггеру избыточным. После своих лекционных курсов о Ницше, претендующих на окончательную переориентацию западного мышления в сторону преодоления метафизики, философ не задумываясь отверг интерпретацию поэта как поверхностную и малосостоятельную. «Кстати, Бенн начинает меня разочаровывать» (письмо от 2.I0.I95I) [I, с. I35], - мимоходом роняет он в послании к Ханне Арендт, имея в виду не только речь, приуроченную к годовщине смерти Ницше, но и итоговый доклад «Проблемы лирики», прозвучавший по радио в г95I г. Хотя творчество Бенна Хайдеггер оценивал чрезвычайно высоко, он не принимал всерьез его теоретических построений, причем не важно, касались ли таковые вторжения поэтической мысли на территорию философии или же обращались к собственным идейным основаниям. В беседе с Ген-

9 Отвечая на опросник издателя Нидермайера, Хайдеггер отметил стихотворение Бенна «На мосту» (I934) в числе трех самых выдающихся, на его взгляд, поэтических опытов XX в. (наряду с «Тайной мира» Гофмансталя и «Испанской трилогией» Рильке), см.: [І3, S. 2I7]. 
рихом Вигандом Петцетом, литературоведом и преданнейшим учеником, Хайдеггер назвал «Проблемы лирики» работой, «плохо написанной», и вообще - сомнительной (см.: [I7, S. 209]).

Несправедливость этого отзыва, вероятно, объясняется тем, что изложенное поэтом существо своего ремесла в корне отличается от хайдеггеровского видения (почти оскорбительно не беря его в расчет). Когда философ объявляет поэзию особой формой искусства, возвышающейся над остальными, потому что от нее они заимствуют сам способ своего poiesis'a, он ни на йоту не отступается от изложенной им в «Истоке художественного творения» трактовки произведения как обнаружения истины бытия. И все последующее выдвижение языка на передний план также вписано в бытийную парадигму его учения, где слову отводится почетная, но второстепенная роль - быть вместилищем вещей в их «изначальной», «подлинной» сути. Бенн же отвергает хайдеггеровский метод обожествления логоса за счет причастности к бытию. Для него стихотворение - не просто «голос бытия», а самостоятельное, автономное существование, «жизнь для себя».

Дитер Томэ в обстоятельном труде «Время самости и время после», представляющем собой текстологический анализ работ Хайдеггера, тоже обращает внимание на его принципиальное разномыслие с Бенном касательно вопроса места и предназначения поэзии. По мнению Томэ, острая реакция философа на программный доклад Бенна («Это попахивает заносчивостью в отношении вещей» [20, S. I57] - таков был его приговор) продиктована обидой на то, что «в действительности Бенн в своей лирике не следовал девизу Хайдеггера - позволить “затронуть себя мироучреждающей сущности вещи” и таким образом быть “в строгом смысле слова” тем,

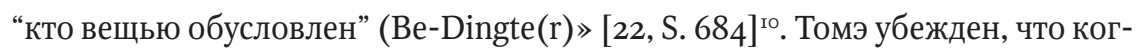
да поэт, не называя имен, говорит:

Мне всегда было необычайно интересно наблюдать, как ученые специалисты, даже и глубокие философы, неожиданно натыкались на свободное слово, к которому нельзя применить никаких тирад, систем или исторически обусловленных наблюдений, никаких комментариев, только образ. Что тут начиналось! Полный провал! [2, с. 227], - 
он подразумевает лично Хайдеггера. Основной упрек, который Бенн бросает философу, заключается в неспособности экзистенциально со-ответствовать «свободному слову» - как в плане его рецепции (если дело касается поэзии), так и в смысле умения с ним обращаться (если речь идет о философии $)^{\mathrm{II}}$.

Стремление Хайдеггера придать языку статус онтологического пространства, в котором вещи являют себя в свете истины, исходило из лучших побуждений и, как следствие, породило большое количество лингвистически ориентированных философских проектов. Однако слово в учении Хайдеггера оказывается подначальным вещи, которую оно призвано вывести в ином, отличном от повседневного, ракурсе «подлинно сущего». Для Бенна же реальность, мир, наполненный вещами, есть нечто противоположное поэтической речи, устремленной к трансценденции. Поэтому любые попытки зафиксировать «свободное слово» в бытии посягают прежде всего на его свободу. «Лирика - либо запредельна, либо ее вообще нет. Таково ее существо» $[7$, с. 394].

\section{Список литературы}

Арендт X., Хайдеггер М. Письма І925-1975 и другие свидетельства / пер. с нем.

А.Б. Григорьева. М.: Изд-во Ин-та Гайдара, 2015. 456 с.

2 Бенн Г. Двойная жизнь / пер. с нем. И. Болычева // Бенн Г. Двойная жизнь. Проза. Эссе. Избранные стихи / сост. И. Болычева, В. Вебера. Изд. 2-е, стереотипное. М.: Летний сад, 2015. С. 162-239. Бенн Г. Досадно / пер. с нем. В. Микушевича // Бенн Г. Перед концом света / сост., вступ. статья и комментарии В. Б. Микушевича. СПб.: Владимир Даль, 2008.

С. 202-203.

4 Бенн Г. Идеальное существование? / пер. с нем. В. Топорова // Бенн Г. Собрание стихотворений / сост., предисл., примеч. и пер. с нем. В. Топорова. СПб.: Евразия, I997. С. 367-369.

5 Бенн Г. Малое культурное обозрение / пер. с нем. В. Топорова // Бенн Г. Собрание стихотворений / сост., предисл., примеч. и пер. с нем. В. Топорова. СПб.: Евразия, I997. С. $482-485$.

II «Стоило бы подвергнуть отдельному исследованию то, в какой мере хайдеггеровский отказ от “свободного слова” (в понимании Бенна) ведет к тому, что его язык, сколь бы поэтичным он ни был, остается таким оцепенелым и тяжеловесным» [22, S. 685]. 
Бенн Г. Ницше 50 лет спустя / пер. с нем. Е. Фетисова // Бенн Г. Двойная жизнь. Проза. Эссе. Избранные стихи / сост. И. Болычева, В. Вебера. Изд. 2-е, стереотипное. М.: Летний сад, 20I5. С. 377-385. Бенн Г. Проблемы лирики / пер. с нем. И. Болычева // Бенн Г. Двойная жизнь. Проза. Эссе. Избранные стихи / сост. И. Болычева, В. Вебера. Изд. 2-е, стереотипное. М.: Летний сад, 20I5. С. 386-4II.

Бенн Г. Старость как проблема художника / пер. с нем. А. Белобратова // Бенн $\Gamma$. Двойная жизнь. Проза. Эссе. Избранные стихи / сост. И. Болычева, В. Вебера. Изд. 2-е, стереотипное. М.: Летний сад, 20I5. С. 424-445. Бенн Г. Эрнсту Юнгеру // Бенн Г. Собрание стихотворений / сост., предисл., примеч. и пер. с нем. В. Топорова. СПб.: Евразия, І997. С. 480-48I. Томэ Д. Был ли Хайдеггер антисемитом? О «Черных тетрадях» и нынешнем положении критики Хайдеггера / пер. с нем. Д. Хамис // Логос. 20I8. Т. 28, №3. C. I2I-I48. Хайдеггер М. Исток художественного творения / пер. с нем. А. В. Михайлова // Хайдеггер М. Работы и размышления разных лет. М.: Гнозис, I993. С. 47-I32. Benn G, Jünger E. Briefwechsel I949-I956 / hrsg. von H. Hof. Stuttgart: Klett-Cotta, 2006. I54 S.

I3 Benn G. Briefe. Band 8: Briefe an den Limes Verlag. I948-I958 / hrsg. und kommentiert von M. V. Schlüter und H. Hof. Stuttgart: Klett-Cotta, 2006. 27I S.

I4 Benn G., Oelze F. W. Briefwechsel I932-I956. Band 2: 1942-I948 / hrsg. von H. Steinhagen und kommentiert von St. Kraft. Göttingen: Klett-Cotta, Wallstein Verlag, 20I6. 573 S.

I5 Benn G., Oelze F. W. Briefwechsel I932-I956. Band 3: I949-I950 / hrsg. von $\mathrm{H}$. Steinhagen und kommentiert von H. Hof. Göttingen: Klett-Cotta, Wallstein Verlag, 20I6. 56I S.

i6 Benn G., Oelze F. W. Briefwechsel I932-I956. Band 4: I95I-I956 / hrsg. von H. Steinhagen und kommentiert von H. Hof. Göttingen: Klett-Cotta, Wallstein Verlag, 20I6. 63I S.

I7 Blenskens H.-J. Gottfried Benn und Martin Heidegger. Respekt und kritischer Bezug // Benn Forum. Beiträge zur literarischen Moderne. Bd. 4, 20I4/20I5 / hrsg. von J. Dyck, H. Korte, N.J. Schmidt. Berlin, Boston: De Gruyter, 2015. S. I95-2Io. Bürger J. «Kluger Mann, witziger Mann». Drei Briefe von Gottfried Benn und Theodor W. Adorno // Zeitschrift für Ideengeschichte. 20I2. Heft VI/3. S. IOI-Io8. Kraft St. Benn, Oelze und das Dritte Reich. Zum Oelzebriefwechsel in Nationalsozialismus // Benn Forum. Beiträge zur literarischen Moderne. Bd. 4, 20I4/20I5 / hrsg. von J. Dyck, H. Korte, N. J. Schmidt. Berlin, Boston: De Gruyter, 20I5. S. II-32. Heidegger 1929-I976. Frankfurt a.M.: Societaets-Verlag, I983. 253 S. 


\section{References}

Schröder J. Gottfried Benn: Poesie und Sozialisation. Stuttgart, Berlin, Köln, Meinz: Kohlhammer, I978. 220 S.

Thomä D. Die Zeit des Selbst und die Zeit danach: zur Kritik der Textgeschichte Martin Heideggers I9I0-I976. Frankfurt a.M.: Suhrkamp, I990. 964 S.

Arendt Kh., Khaidegger M. Pis'ma I925-I975 i drugie svidetel'stva [The letters of the I925-1975 and other evidence], transl. from German by A. B. Grigoriev. Moscow, Izd-vo Instituta Gaidara Publ., 20I5. 456 p. (In Russ.)

Benn G. Dvoinaia zhizn' [Double life], transl. from German by I. Bolychev. Benn G. Dvoinaia zhizn'. Proza. Esse. Izbrannye stikhi [Double life. Prose. Essays. Selected Poems], ed. by I. Bolychev, V. Veber. Moscow, Letnii sad Publ., 2015, pp. I62-239. (In Russ.)

Benn G. Dosadno [Annoying], transl. from German by V. Mikushevich. Benn G. Pered kontsom sveta [Before the end of the world], ed. by V. B. Mikushevich. St. Petersburg, Vladimir Dal' Publ., 2008, pp. 202-203. (In Russ.)

Benn G. Ideal'noe sushchestvovanie? [A perfect existence], transl. from German by V. Toporov. Benn G. Sobranie stikhotvorenii [Collection of poems], ed. by V. Toporov. St. Petersburg, Evraziia Publ., 1997, pp. 367-369. (In Russ.)

Benn G. Maloe kul'turnoe obozrenie [Small culture review], transl. from German by V. Toporov. Benn G. Sobranie stikhotvorenii [Collection of poems], ed. by V. Toporov. St. Petersburg, Evraziia Publ., I997, pp. 482-485. (In Russ.)

Benn G. Nitsshe 50 let spustia [Nietzsche after fifty jears], transl. from German by E. Fetisov. Benn G. Dvoinaia zhizn’. Proza. Esse. Izbrannye stikhi [Double life. Prose. Essays. Selected Poems], ed. by I. Bolychev, V. Veber. Moscow, Letnii sad Publ., 20I5, pp. 377-385. (In Russ.)

7 Benn G. Problemy liriki [Problems of lyrical poetry], transl. from German by I. Bolychev. Benn G. Dvoinaia zhizn'. Proza. Esse. Izbrannye stikhi [Double life. Prose. Essays. Selected Poems], ed. by I. Bolychev, V. Veber. Moscow, Letnii sad Publ., 20I5, pp. 386-4II. (In Russ.)

8 Benn G. Starost' kak problema khudozhnika [Old age as the problem of the artist], transl. from German by A. Belobratov. Benn G. Dvoinaia zhizn'. Proza. Esse. Izbrannye stikhi [Double life. Prose. Essays. Selected poems], ed. by I. Bolychev, V. Veber. Moscow, Letnii sad Publ., 20I5, pp. 424-445. (In Russ.)

9 Benn G. Ernstu Iungeru [To Ernst Junger], transl. from German by V. Toporov. Benn G. Sobranie stikhotvorenii [Collection of poems], ed. by V. Toporov. St. Petersburg, Evraziia Publ., I997, pp. 480-48I. (In Russ.)

Io Tome D. Byl li Khaidegger antisemitom? O "Chernykh tetradiakh" i nyneshnem polozhenii kritiki Khaideggera [Was Heidegger an anti-semite? On the black notebooks 
and the current state of Heidegger criticism], transl. from German by D. Khamis. Logos, 20I8, vol. 28, no 3, pp. I2I-I48. (In Russ.)

Khaidegger M. Istok khudozhestvennogo tvoreniia [The origin of the work of art], transl. from German by A.V. Mikhailov. Khaidegger M. Raboty i razmyshleniia raznykh let [Works and reflections of different years]. Moscow, Gnozis Publ., I993, pp. 47-I32. (In Russ.)

Benn G., Jünger E. Briefwechsel 1949-1956, hrsg. von H. Hof. Stuttgart, Klett-Cotta, 2006. I54 S. (In German)

I3 Benn G. Briefe, Band 8: Briefe an den Limes Verlag. 1948-1958, hrsg. und kommentiert von M. V. Schlüter und H. Hof. Stuttgart, Klett-Cotta, 2006. 27I S. (In German)

I4 Benn G., Oelze F. W. Briefwechsel I932-I956, Band 2: 1942-1948, hrsg. von H. Steinhagen und kommentiert von St. Kraft. Göttingen, Klett-Cotta, Wallstein Verlag, 20I6. 573 S. (In German)

I5 Benn G., Oelze F. W. Briefwechsel 1932-1956, Band 3: 1949-1950, hrsg. von H. Steinhagen und kommentiert von H. Hof. Göttingen, Klett-Cotta, Wallstein Verlag, 2016. 56I S. (In German)

I6 Benn G., Oelze F. W. Briefwechsel I932-1956, Band 4: 1951-1956, hrsg. von H. Steinhagen und kommentiert von H. Hof. Göttingen, Klett-Cotta, Wallstein Verlag, 20I6. 63I S. (In German)

I7 Blenskens H.-J. Gottfried Benn und Martin Heidegger. Respekt und kritischer Bezug. Benn Forum. Beiträge zur literarischen Moderne, Bd. 4, 20I4/20I5, hrsg. von J. Dyck, H. Korte, N. J. Schmidt. Berlin, Boston, De Gruyter, 20I5, S. I95-2IO. (In German) Bürger J. “Kluger Mann, witziger Mann”. Drei Briefe von Gottfried Benn und Theodor W. Adorno. Zeitschrift für Ideengeschichte, 20I2, Heft VI/3, S. IOI-IO8. (In German)

I9 Kraft St. Benn, Oelze und das Dritte Reich. Zum Oelzebriefwechsel in Nationalsozialismus, Benn Forum. Beiträge zur literarischen Moderne, Bd. 4, 20I4/20I5, hrsg. von J. Dyck, H. Korte, N.J. Schmidt. Berlin, Boston, De Gruyter, 20I5, S. II-32. (In German)

20 Petzet H.W. Auf einen Stern zugehen: Begegnungen und Gespräche mit Martin Heidegger 1929-1976. Frankfurt am Main, Societaets-Verlag, I983. 253 S. (In German) Schröder J. Gottfried Benn: Poesie und Sozialisation. Stuttgart, Berlin, Köln, Meinz, Kohlhammer, I978. 220 S. (In German) Thomä D. Die Zeit des Selbst und die Zeit danach: zur Kritik der Textgeschichte Martin Heideggers I9I0-1976. Frankfurt am Main, Suhrkamp, I990. 964 S. (In German) 